\title{
PENAMBATAN MOLEKULER SENYAWA XANTON PADA KULIT BUAH MANGGIS (Garcinia Mangostana L.) DENGAN ENZIM COX-2 Sebagai Kandidat Antikanker Payudara.
}

\author{
Herson Cahaya Himawan*1., Lilik Sulastri²., Verari Vernando3
}

\author{
1. Program Studi Farmasi Sekolah Tinggi Teknologi Industri dan Farmasi Bogor \\ 2. Program Studi Farmasi Sekolah Tinggi Teknologi Industri dan Farmasi Bogor \\ 3. Mahasiswa Program Studi S1 Farmasi Sekolah Tinggi Teknologi Industri dan Farmasi \\ Bogor \\ Korespondensi: hersonindonesia2011@gmail.com
}

\begin{abstract}
ABSTRAK
Kanker payudara merupakan salah satu jenis kanker yang paling umum diderita oleh wanita diseluruh dunia. Kanker payudara diketahui memiliki kaitan erat dengan inflamasi kronis yang dikontrol oleh siklooksigenase-2 (COX-2). Kulit buah manggis (Garcinia mangostana L.) mengandung senyawa golongan xanton. Senyawa tersebut memiliki potensi sebagai inhibitor enzim COX-2. Tujuan dari penelitian ini adalah untuk mengetahui senyawa yang paling aktif dari senyawa xanton. Potensi senyawa xanton diuji toksisitasnya mengunakan Toxtree, analisis toksisitas difokuskan pada karsinogenisitas dan mutagenisitas.Hasil uji toksisitas senyawa ligan dengan perangkat lunak Toxtree didapatkan hasil bahwa senyawa 1-Isomangostin hydrate, 3-Isomangostin hydrate, Euxanthon, BR-xanthone A, Garcimangosone B dan Garcimangosone D diprediksi aman untuk digunakan sebagai obat. Kemudian senyawa tersebut dianalisis berdasarkan kriteriaLipinski's Rule of Fiveuntuk memprediksi penyerapan obat dalam tubuh.Hasil analisis menunjukkan, lima senyawa hasil analisis memenuhi kriteria-kriteriaLipinski kecuali Garcimangosone D. Selanjutnya dilakukan penambatan molekuler menggunakan Autodock Vina. BR-xanthone A memiliki energi ikatan $(\Delta \mathrm{G})$ terbaik yaitu $-10,1 \mathrm{kkal} / \mathrm{mol}$ jika dibandingkan dengan senyawa uji lainnya,dan mendekati energi ikatan $(\Delta \mathrm{G})$ senyawa pembanding selekoksib -12,4 kkal/mol.
\end{abstract}

\section{Kata kunci: Kanker payudara, penambatan molekuler, COX-2, ksanton.}

\begin{abstract}
Breast cancer is one of the most common types of cancer suffered by women around the world. Breast cancer is known that has relationship with chronic inflammation that is controlled by cyclooxygenase-2 (COX-2). Pericarp of mangosteen (Garcinia mangostana L.) contains a class compound of xanthone. The compound has potential as an inhibitor of the COX-2enzyme.The purpose of this research is to know the most active compound of xanthone compounds. Potential of xanthone compounds tested the toxicityby using Toxtree, the analysis of toxicity is focused on the carcinogenycity and mutagenicity. The result of toxicity test of ligand compound with Toxtree software found that the compound of 1-Isomangostin hydrate, 3-Isomangostin hydrate, Euxanthon, BR-xanthone A,Garcimangosone B and Garcimangosone D predicted safe for use as medicine. Then the compound itself analyzed based on the criteria of Lipinski's Rule of Five to predict the drug absorption in the human body. The analysis showed,five compounds fulfilled the criteria of Lipinski except Garcimangosone D. Further analysis was molecular docking using Autodock VinaA had a binding energy $(\Delta \mathrm{G})$ the best that was $-10.1 \mathrm{kcal} / \mathrm{mol}$ if it compared to other test compounds, approaching the binding energy $(\Delta \mathrm{G})$ comparative compound of celecoxib $-12.4 \mathrm{kcal} / \mathrm{mol}$.
\end{abstract}

Keyword: Breast cancer, moleculer docking, COX-2, xanthone 


\section{PENDAHULUAN \\ Latar Belakang}

Kanker payudara adalah kanker yang paling umum menyerang wanita di seluruh dunia [1].Pengobatan kanker payudara yang selama ini telah dilakukan berupa pembedahan, kemoterapi, radioterapi, terapi dengan hormon atau dengan terapi antibodi monoclonal [2] Beberapa obat komersialyang berkhasiat sebagai antikanker payudara memiliki efek samping yang berbahaya bagi tubuh. Oleh karena itu, perlu dilakukan pengembangan senyawa obat baru yang lebih aman dan efektif dari bahan alam. Salah satunya adalah kulit buah manggis (Garcinia mangostana L.).Kulit buah manggis (Garcinia Manggostana L.) adalah sumber xanton dan zat bioaktif lainnya. Beberapa penelitian sebelumnya menunjukkan bahwa ekstrak kulit manggis memiliki aktivitas sitotoksik yang kuat pada sel MCF-7 dengan $\mathrm{IC}_{50}$ sebesar $45 \mu \mathrm{g} / \mathrm{mL}$ melalui mekanisme apoptosis [3]Beberapa senyawa xanton yang diketahui memiliki aktivitas terhadap sel kanker payudara, $\alpha$ mangostin mempunyai aktivitas apoptosis pada sel kanker payudara MDA-MB231

[4] Kanker payudara telah diketahui memiliki hubungan yang erat dengan inflamasi kronis. Inflamasi didalam sel dikontrol oleh enzim COX-2. Enzim COX2 yang berperan mensintesis prostaglandin ini, diketahui memilikikaitan dengan perkembangan kanker payudara. Sintesis berlebihan pada COX-2 ditemukan pada kanker payudara [5]). Penghambatan pada enzim COX-2 berpotensi untuk dikembangkan sebagai obat antikanker payudara. Mekanisme interaksi antara COX-2 dan senyawa xanton ini dapat diteliti dengan metode penambatan molekuler.Pada penelitian ini akan dilakukan pencarian kandidat obat antikanker payudara menggunakan metode penambatan molekuler.Senyawa xanton dari kulit buah manggis (Garcinia

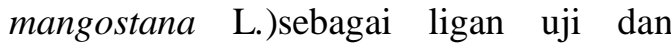
selekoksib sebagai kontrol positif denganenzim COX-2sebagai reseptor.

Penambatan molekuler pada penelitian ini menggunakan perangkat lunak Autodock Vina. Penelitian ini diharapkan dapat memberikan gambaran interaksi antara beberapa senyawa xanton dengan enzim COX-2.

\section{METODE PENELITIAN}

Bahan : Struktur 3DMakromolekul Struktur 3D COX-2 diunduh dari Protein Data Bank (PDB) melalui situs [6]. Makromolekul protein yang dipilih adalah COX-2 dari Mus musculus yang didapat dari metode kristalografi X-ray dengan resolusi 2,4 $\AA$. Identitas makromolekul tersebut adalah 3LN1 dengan format

*.pdb. Struktur 3D Ligan Struktur 3D ligan yang digunakan adalah senyawa xanton dari kulit buah manggis (Garcinia mangostana L.) dan sebagai pembanding selekoksib.Struktur 3D ligan-ligan tersebut diunduh dari Pubchem melalui situs [7].

Alat: Perangkat KerasNotebook Asus (AR5B125) dengan spesifikasi Intel(R) Celeron(R) CPU 847 @ $1.10 \mathrm{GHz}$ $1.10 \mathrm{GHz}$, RAM (Random Access Memory) 4,0 gigabyte (3,40 gigabyte usable), kartu grafis (Intel (R) HD Graphics). Notebookterhubung dengan AC/DC adapter dan terkoneksi internet.Perangkat Lunak

Sistem Operasi Windows 7 Ultimate 32 bit, paket AutodockTools yang terdiri atas Python 2.7.13 dan MGLTools 1.5.6 (Scripps Research Institute), Open Babel 2.4.1, Discovery Studio Visualizer 2016 (Accelrys Enterprise Platform), Autodock Vina , Pymol (Delano Scientific LLC.), LigPlot+, Marvin Sketch, Toxtree dan situs [7]

\section{Metode \\ Penyiapan Struktur Makromolekul}

Makromolekul COX-2 diunduh dari Protein Data Bank (PDB) dengan situs [6] Identitas makromolekul yang akan digunakan yaitu3LN1. Data makromolekul diunduh dalam format *.pdb.Makromolekul protein dipisahkan dari pelarut dan ligan yaitu residu non standar. Pemisahan makromolekul dari molekul yang tidak diperlukan dilakukan dengan menggunakan program Discovery Studio Visualizer 2016. Hasil pemisahan tersebut akan digunakan untuk penambatan molekuler. Hasil pemisahan disimpan dalam format *.pdb. Makromolekul yang 


\section{6|Herson Himawan et al. ( Penambatan Molekuler Senyawa ...)}

telah dipisahkan dari residu dioptimasi dengan AutodockTools. Optimasi tersebut meliputi: penambahan atom hidrogen dan pengaturan grid boxparameter. Hasil ini disimpan dalam format *.pdbqt.

\section{Penyiapan Struktur Ligan}

Struktur ligan-liganyang digunakan untuk pengujian berupa struktur 3D. Struktur 3D ligan-ligan diunduh dari PubChem dengan format *.sdf. Format ligan-ligan ini kemudian diubah menjadi *.pdb dengan menggunakan program Open Babel.Selanjutnya ligan-ligan tersebut dioptimasi dengan menggunakan AutodockTools. Optimasi tersebut berupa pengaturan number of active torsion. Hasil optimasi disimpan dalam format *.pdbqt.

\section{Uji Toksisitas}

Uji toksisitas dilakukan menggunakan perangkat lunak Toxtree. Parameter yang akan digunakan adalah prediksi tingkat karsinogenisitas dan mutagenisitas dari ligan. Prediksi ini dilakukan dengan menginput ligan dalam format*.sdf. Selanjutnya dipilih metode penentuan kriteria toksisitas pada senyawa. Estimasi dilakukan untuk melihat penentuan kriteria toksisitas suatu senyawa berdasarkan Toxtree.

\section{Analisis Lipinski's Rule of Five}

Analisis dilakukan dengan menggunakan Marvin Sketch. Kriteria Lipinski's Rule of Five terdiri dari berat molekul (kurang dari 500), jumlah hidrogen donor (tidak lebih dari 5 gugus hidrogen donor), jumlah akseptor hidrogen (tidak lebih dari 10 gugus hidrogen akseptor), nilai $\log \mathrm{P}$ (tidak lebih dari 5) dan koefisien molar sebaiknya diantara 40130.

\section{Validasi Metode Penambatan Molekuler}

Validasi penambatan molekuler dilakukan menggunakan Pymol. Validasi Evaluasi RMSD dilakukan dengan menentukan menentukan nilai RMSD berdasarkan rentang sebagai berikut: RMSD $\leq 1 \AA$ untuk konformasi yang baik atau menyerupai yang sebenarnya, $1 \AA<$ RMSD $\leq 2 \AA$ untuk konformasi yang mendekati sebenarnya, $2 \AA<$ RMSD $\leq 3 \AA$ untuk konformasi dengan kesalahan dan RMSD> $3 \AA$ untuk konformasi yang buruk.

\section{Penambatan Molekuler}

Penambatan molekuler dilakukan menggunakan Autodock Vina. Protein dan ligan yang telah disimpan dalam format *.pdbqt disalin ke dalam folder Vina. Kemudian konfigurasi file vina diketik pada notepad, disimpan dengan nama "conf.txt". Jumlah pengulangan (exaustiveness) dilakukan sebanyak 8 kali. Vina dijalankan melalui Command Prompt.

\section{HASIL DAN PEMBAHASAN \\ Hasil Penyiapan Struktur \\ Makromolekul}

Struktur makromolekul yang digunakan diperoleh dari Protein Data Bank. Identitas makromolekul yang dipilih adalah $3 \ln 1$. Makromolekul yang diunduh terikat dengan ligan dan molekul air. Ligan dan molekul air harus dihilangkan dari makromolekul karena dapat mengganggu dalam proses penambatan molekuler.Hasil penyiapan struktur molekul dapat dilihat pada gambar 1

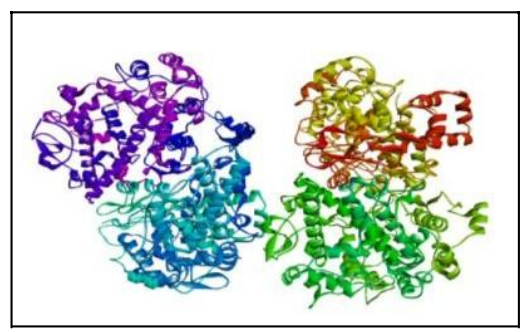

Gambar 1. Visualisasi Struktur 3D Siklooksigenase-2 dengan

Discovery Studio Visualizer 2016. 


\section{7|Herson Himawan et al. ( Penambatan Molekuler Senyawa ...)}

Hasil Penyiapan Struktur Ligan

Struktur senyawa aktif dari kulit buah manggis (Garcinia mangostana L.) yang digunakan merupakan hasil penelusuran pustaka. Sebagai senyawa pembandingdigunakan selekoksib.Struktur ligan yang digunakan dalam penelitian ini berupa struktur 3D (Gambar2).

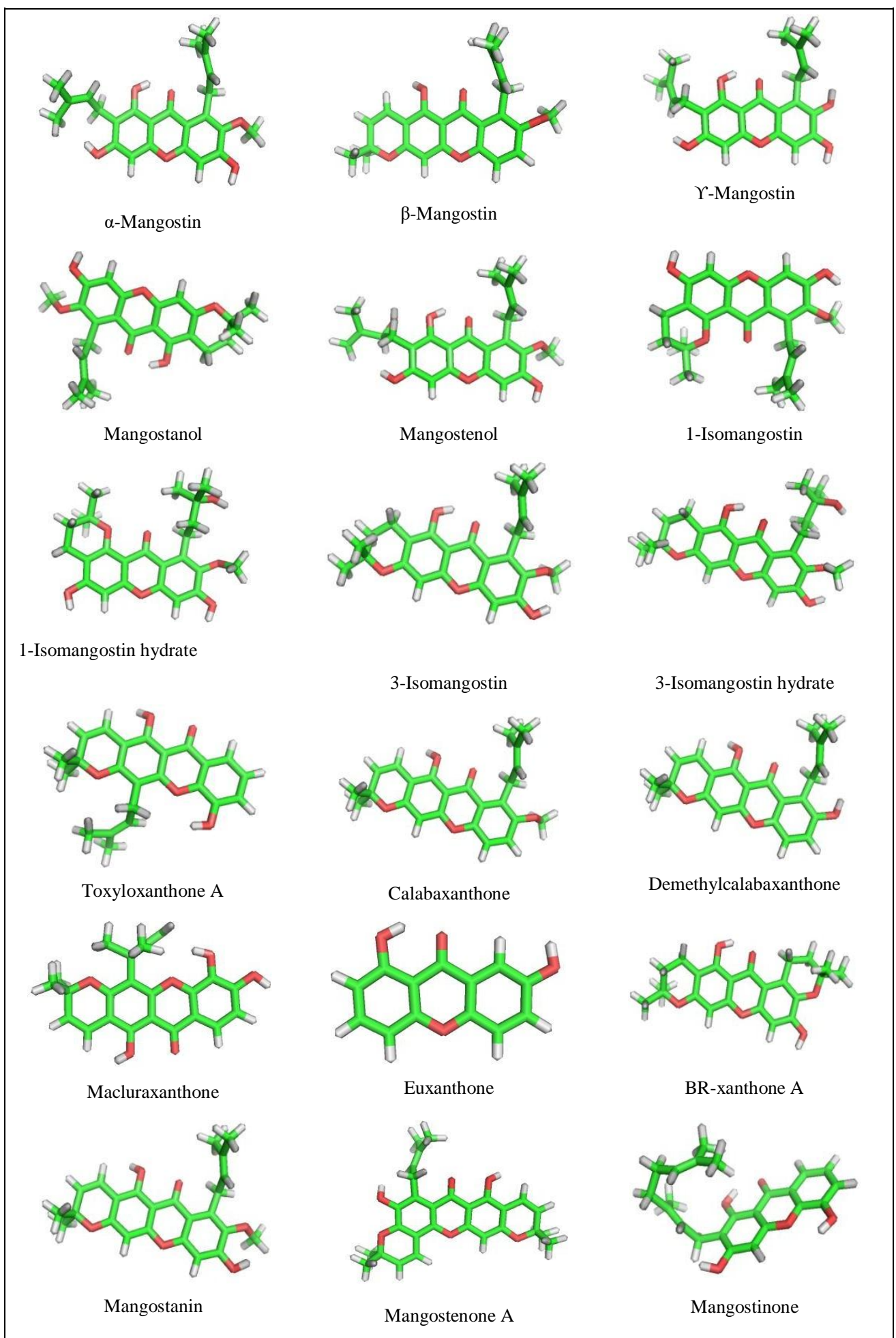




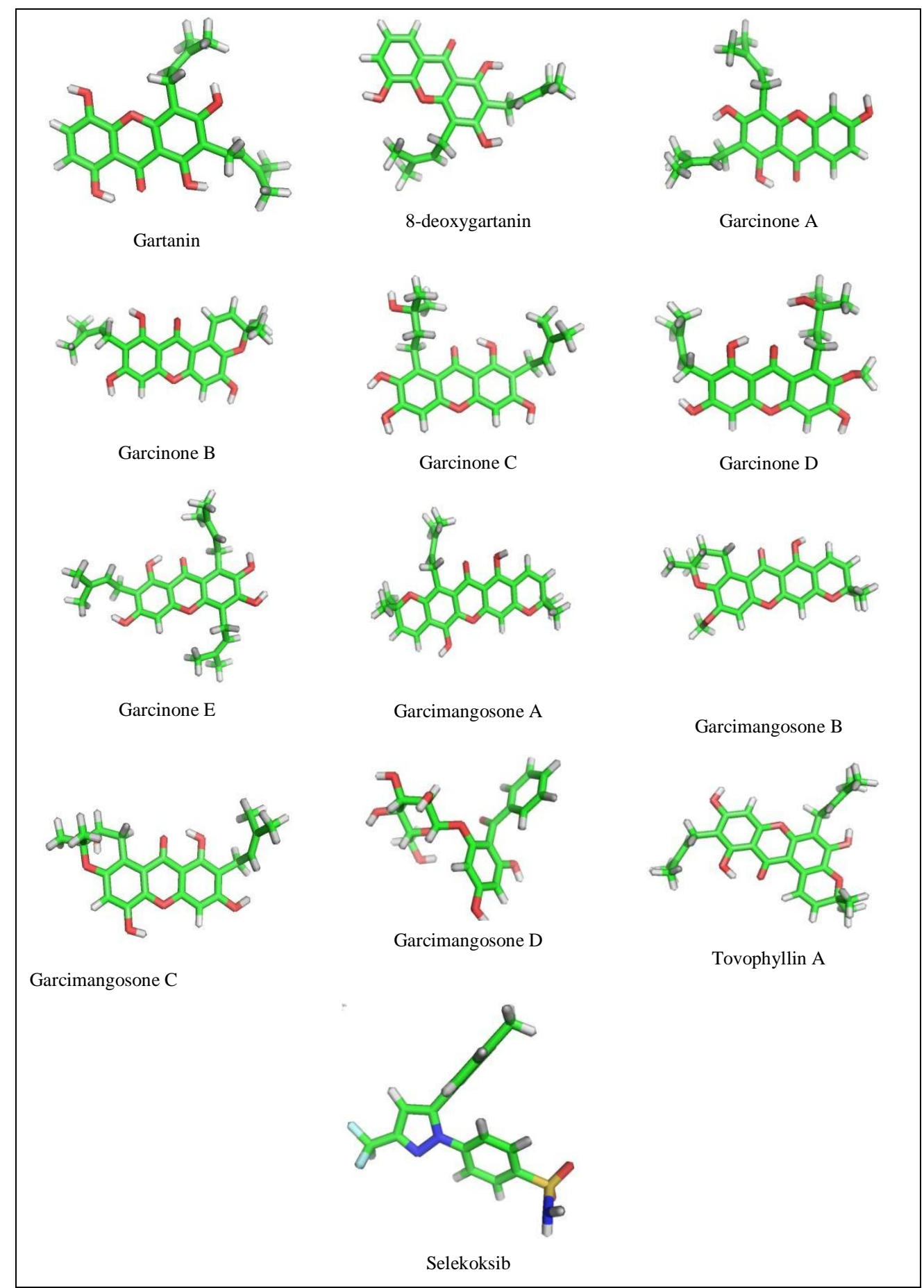

Keterangan: Hijau (atom C), abu-abu (atom H), merah (atom O), biru (atom N), Kuning (atom $\mathrm{S}$ ), biru kehijauan (atom F)

\section{Gambar 2. Struktur 3D Ksanton dan Selekoksib}

\section{Uji Toksisitas}

Prediksi toksisitas ligan bertujuan untuk mengetahui karakter daya toksisitas dari masing-masing ligan. Hal ini perlu dilakukan untuk memprediksi efek merugikan yang dapat ditimbulkan jika digunakan untuk pengobatan. Pada penelitian ini, penentuan sifat toksisitas dilakukan menggunakan perangkat lunak Toxtree. Sifat toksikologi difokuskan pada sifat karsinogenisitas dan sifat mutagenisitas . Hasil uji toksisitas dapat dilihat pada tabel 1 
39|Herson Himawan et al. ( Penambatan Molekuler Senyawa ...)

Tabel 2. Prediksi toksisitas berdasarkan aturan Benigni/ Bossa

\begin{tabular}{|c|c|c|c|c|c|c|c|}
\hline \multirow{2}{*}{ No } & \multirow{2}{*}{ Senyawa } & \multicolumn{6}{|c|}{ Parameter } \\
\hline & & $\mathrm{A}$ & $\mathrm{B}$ & $\mathrm{C}$ & $\mathrm{D}$ & $E$ & $\mathrm{~F}$ \\
\hline 1 & $\alpha$-Mangostin & $\sqrt{ }$ & - & - & - & - & $\sqrt{ }$ \\
\hline 2 & $\beta$-Mangostin & $\sqrt{ }$ & - & - & - & - & $\sqrt{ }$ \\
\hline 3 & $\Upsilon$-Mangostin & $\sqrt{ }$ & - & - & - & - & $\sqrt{ }$ \\
\hline 4 & Mangostanol & $\sqrt{ }$ & - & - & - & - & $\sqrt{ }$ \\
\hline 5 & Mangostenol & $\sqrt{ }$ & - & - & - & - & $\sqrt{ }$ \\
\hline 6 & 1-Isomangostin & $\sqrt{ }$ & - & - & - & - & $\sqrt{ }$ \\
\hline 7 & 1-Isomangostin hydrate & - & - & - & - & $\sqrt{ }$ & $\sqrt{ }$ \\
\hline 8 & 3-Isomangostin & $\sqrt{ }$ & - & - & - & - & $\sqrt{ }$ \\
\hline 9 & 3-Isomangostin hydrate & - & - & - & - & $\sqrt{ }$ & $\sqrt{ }$ \\
\hline 10 & Toxyloxanthone A & $\sqrt{ }$ & - & - & - & - & $\sqrt{ }$ \\
\hline 11 & Calabaxanthone & $\sqrt{ }$ & - & - & - & - & $\sqrt{ }$ \\
\hline 12 & Demethylcalabaxanthone & $\sqrt{ }$ & - & - & - & - & $\sqrt{ }$ \\
\hline 13 & Macluraxanthone & $\sqrt{ }$ & - & - & - & - & $\sqrt{ }$ \\
\hline 14 & Euxanthone & - & - & - & - & $\sqrt{ }$ & $\sqrt{ }$ \\
\hline 15 & BR-xanthone A & - & - & - & - & $\sqrt{ }$ & $\sqrt{ }$ \\
\hline 16 & Mangostanin & $\sqrt{ }$ & - & - & - & - & $\sqrt{ }$ \\
\hline 17 & Mangostenone A & $\sqrt{ }$ & - & - & - & - & $\sqrt{ }$ \\
\hline 18 & Mangostinone & $\sqrt{ }$ & - & - & - & - & $\sqrt{ }$ \\
\hline 19 & Gartanin & $\sqrt{ }$ & - & - & - & - & $\sqrt{ }$ \\
\hline 20 & 8-deoxygartanin & $\sqrt{ }$ & - & - & - & - & $\sqrt{ }$ \\
\hline 21 & Garcinone A & $\sqrt{ }$ & - & - & - & - & $\sqrt{ }$ \\
\hline 22 & Garcinone B & $\sqrt{ }$ & - & - & - & - & $\sqrt{ }$ \\
\hline 23 & Garcinone C & $\sqrt{ }$ & - & - & - & - & $\sqrt{ }$ \\
\hline 24 & Garcinone D & $\sqrt{ }$ & - & - & - & - & $\sqrt{ }$ \\
\hline 25 & Garcinone E & $\sqrt{ }$ & - & - & - & - & $\sqrt{ }$ \\
\hline 26 & Garcimangosone A & $\sqrt{ }$ & - & - & - & - & $\sqrt{ }$ \\
\hline 27 & Garcimangosone B & - & - & - & - & $\sqrt{ }$ & $\sqrt{ }$ \\
\hline 28 & Garcimangosone $\mathrm{C}$ & $\sqrt{ }$ & - & - & - & - & $\sqrt{ }$ \\
\hline 29 & Garcimangosone D & - & - & - & - & $\sqrt{ }$ & $\sqrt{ }$ \\
\hline 30 & Tovophyllin A & $\sqrt{ }$ & - & - & - & - & $\sqrt{ }$ \\
\hline 31 & Selekoksib & - & - & - & - & $\sqrt{ }$ & $\sqrt{ }$ \\
\hline
\end{tabular}


Ket:
A. Peringatan struktur untuk sifat genotoksik karsinogenik
B. Peringatan struktur untuk sifat nongenotoksik karsinigenik
C. Potensi karsinogen berdasarkan QSAR
D. Potensi mutasi oleh S.tyhimurium berdasarkan QSAR
E. Tidak bersifat genotoksik karsinogenik
F. Tidak bersifat nongenotoksik karsinogenik

Hasil prediksi toksisitas 30 senyawa xanton dari kulit buah manggis di simpulkan bahwa 24 senyawa diprediksi positif bersifat karsinogen dan 6 senyawa bersifat tidak karsinogen. Substruktur senyawa xanton yang bertangung jawab atas karsinogenisitas yaitu alkenil benzen.

\section{Analisis Lipinski's Rule of Five}

Senyawa-senyawa kandidat obat ini harus memenuhi lima kriteria lipinski agar bisa diserap dengan optimal oleh tubuh. Kriteria Lipinski terdiri atas: Berat molekul kurang dari 500, jumlah donor hidrogen tidak lebih dari 5, jumlah akseptor hidrogen tidak lebih dari 10, nilai Log P tidak lebih dari 5 dan refraktifitas molar berada antara 40-130 (Lipinski et al., 2001). Hasil analisi Lipinski"s dapat dilihat pada tabel 2

Tabel 3. Aturan Lipinski beberapa senyawa xanton

\begin{tabular}{llccccc}
\hline No & RO5 & $\begin{array}{c}\text { Berat } \\
\text { Molekul }\end{array}$ & $\begin{array}{c}\text { Donor } \\
\text { Hidrogen }\end{array}$ & $\begin{array}{c}\text { Akseptor } \\
\text { Hidrogen }\end{array}$ & $\begin{array}{c}\text { Log } \\
\mathrm{P}\end{array}$ & $\begin{array}{c}\text { Refraktifitas } \\
\text { Molar }\end{array}$ \\
\hline 1 & $\begin{array}{l}\text { 1-Isomangostin } \\
\text { hydrate }\end{array}$ & 428,481 & 3 & 6 & 2,75 & 115,90 \\
& 3-Isomangostin & 428,481 & 3 & 6 & 3,40 & 115,90 \\
2 & hydrate & 228,203 & 2 & 3 & 2,73 & 60,78 \\
3 & Euxanthone & 396,439 & 2 & 5 & 3,96 & 107,64 \\
4 & BR-xanthone A & 408,450 & 1 & 5 & 4,13 & 113,08 \\
5 & Garcimangosone B & 45,360 & 6 & 9 & 0,40 & 94,72 \\
6 & Garcimangosone D & 392,360 & & & & \\
7 & Selekoksib & 381,37 & 1 & 3 & 3,83 & 92,23 \\
\hline
\end{tabular}

Hasil menunjukkan bahwa dari enam senyawa xanton yang dianalisis,

Garcimangosone D tidak memenuhi kelima kriteria Lipinski. Kelima kandidat obat lainnya yang memenuhi kriteria Lipinski yaitu: 1-Isomagostin hydrate, 3Isomangostin hydrate, Euxanthone, dan Garcimangosone B diasumsikan dapat terdistribusi dengan baik di dalam tubuh.

Senyawa yang tidak memenuhi aturan Lipinski tidak disarankankan digunakan secara oral.

\section{Validasi Penambatan Molekuler}

Validasi penambatan molekuler bertujuan untuk mengkalibrasi dan memvalidasi parameter penambatan molekuler yang akan digunakan oleh perangkat Autodock Vina.

RMSD (Root Mean Standart Deviation) merupakan nilai penyimpangan antara satu konformasi ligan natif kristalografi dengan ligan natif hasil optimasi penambatan. Evaluasi RMSD dilakukan dengan menentukan menentukan nilai RMSD berdasarkan rentang sebagai berikut: RMSD $\leq 1 \AA$ untuk konformasi yang baik atau menyerupai yang sebenarnya, $1 \AA<$ RMSD $\leq 2 \AA$ untuk konformasi yang mendekati sebenarnya, 2 


\section{1|Herson Himawan etal. ( Penambatan Molekuler Senyawa ...)}

$\AA<$ RMSD $\leq 3 \AA$ untuk konformasi dengan kesalahan dan RMSD> $3 \AA$ untuk konformasi yang buruk (Bajda, et al., 2014). Hasil validasi penambatan molekuler menggunakan Yasara 1,1353 , hasil ini menunjukkan nilai konformasi yang mendekati sebenarnya dapat dilihat pada Gambar 3.

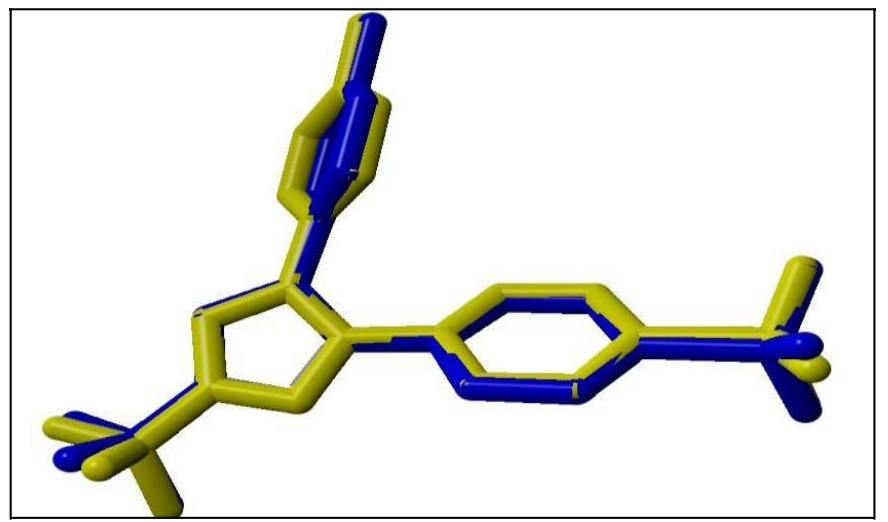

Gambar 3. Konformasi 3D ligan hasil tambat (biru) dengan natif ligan (kuning).

(Yasara, 2017)

Penambatan Molekuler

Penambatan molekuler menggunakan Autodock Vina dapat meningkatkan akurasi dari prediksi mode ikatan bila dibandingkan dengan Autodock 4. Hasilnya penambatan molekuler dapat dilihat pada gambar 4

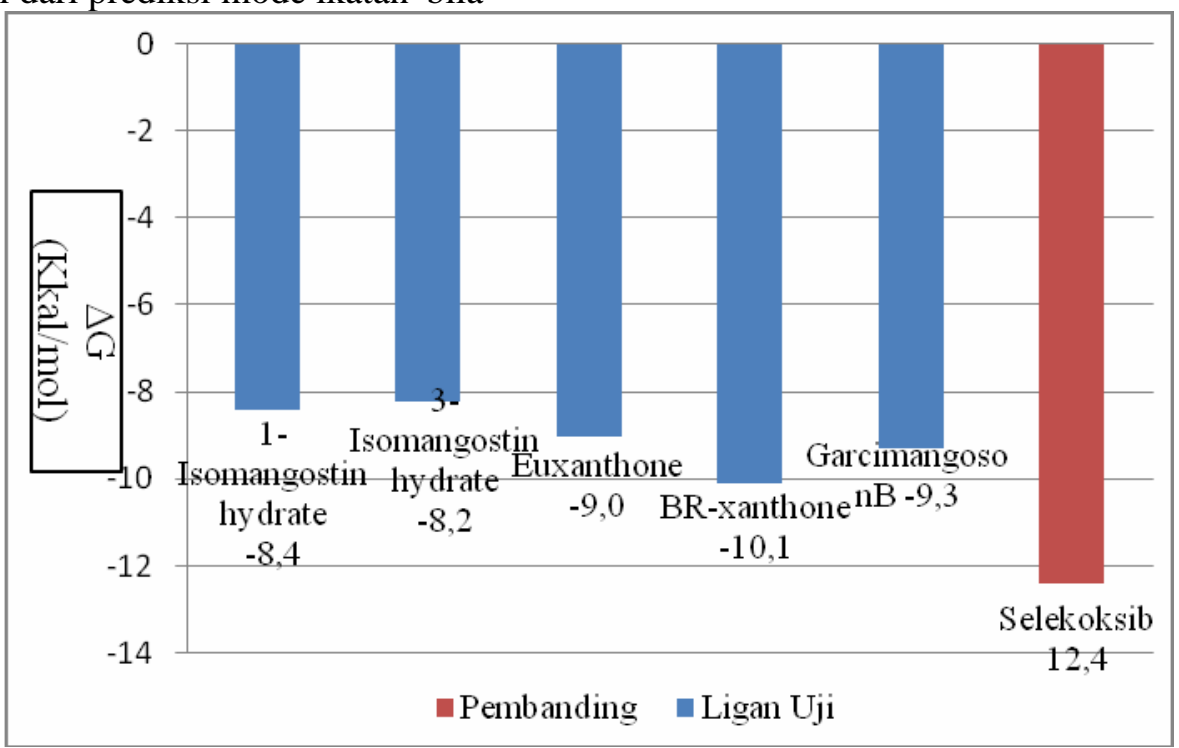

Gambar4. Hasil Penambatan Molekuler Senyawa Xanton dan Selekoksib

Hasil penambatan molekuler menggunakan Autodock Vina menunjukkan nilai energi bebas Gibbs $(\Delta \mathrm{G})$ seluruh ligan uji bernilai negatif.

Dari hasil penambatan molekuler, senyawa uji yang memiliki $\Delta$ Gyang paling negatif adalah BR-xanthone A dengan -10,1 kkal/mol, diikuti oleh Garcimangosone B -9,3 kkal/mol,
Euxanthone $\quad-9,0 \quad \mathrm{kkal} / \mathrm{mol}, \quad 1-$ isomangostin hydrate $-8,4 \mathrm{kkal} / \mathrm{mol}$, dan 3-Isomangostin hydrate $-8,2 \mathrm{kkal} / \mathrm{mol}$. Senyawa pembanding selekoksib memiliki energi afinitas $-12,4 \mathrm{kkal} / \mathrm{mol}$. 


\section{SIMPULAN}

Hasil penambatan molekuler senyawa-senyawa xanton dari kulit buah manggis (Garcinia mangostana L.) dengan enzim COX-2 menunjukkan bahwa BR-xanthone A (-10,1 kkal/mol)memiliki nilai energi bebas $(\Delta \mathrm{G})$ yang mendekati nilai energi bebas $(\Delta \mathrm{G})$ selekoksib $(-12,4 \mathrm{kkal} / \mathrm{mol})$. Senyawa ini juga diprediksi tidak bersifat toksik dan memenuhi aturan Lipinski. Oleh karena itu senyawa BR- xanthone A dari kulit buah manggis (Garcinia mangostana L.) memiliki potensi sebagai kandidat obat antikanker payudara dengan menghambat aktifitas enzim COX-2.

\section{SARAN}

Hasil penambatan molekuler merupakan ramalan aktifitas biologis karena diperoleh dari simulasi pemodelan komputerisasi. Sehingga perlu dilakukan pengujian lebih lanjut validitas penambatan molekuler secara in vitro dan in vivo.

\section{DAFTAR PUSTAKA}

[1] Shah, R., Rosso, K., Nathanson,

S.D. 2014. Pathogenesis, prevention, diagnosis and treatment of breast cancer. World Journal of Clinical Oncology5:283-296.

[2] Mitrasinovic, P.M., Mihajlovic,

M.L. 2008. Recent Advances in Radiation Therapy of Cancer Cells: A Step towards an Experimental and Systems Biology Framework. Current Radiopharmaceutical1:22-29.

[3] Setiawati, A., Riswanto, F. O., Yuliani, S. H., \& Istyastono, E. P. 2014. Anticancer Activity of Mangosteen Pericarp Dry Extract Against MCF-7 Breast Cancer cell line Through Estrogen Receptor- $\alpha$. Indonesian J. Pharm, 25(3).

[4] Kurose, H., Shibata, M.A., Linuma, M., Otsuki, Y. 2012. Alteration in Cell Cycle and Induction of Apoptotic Cell Death in Breast Cancer Cells Treated with Alfa-Mangostin Extracted from Mangosteen Pericarp. Journal of Biomedicine and Biotechnology.

[5] Soslow, R.A.et al. 2000. COX-2 is Expressed in Human Pulmonary, Colonic, and Mammary Tumors. American Cancer Society89:2637-2645

[6] RCSB. 2017. About the PDB Archive and the RCSB PDB: http://www.rcsb.org/pdb/static.do ?p=general_information/about_pd b/index.html [8 Juli 2017]. PubChem. 2017. Open Chemistry Database.http://www.ncbi.nlm.nih gov/compound 6 Juli 2017. 